Poland

\title{
Krzysztof Knittel's Chamber Opera and Agnieszka Stulgińska's Music Theatre: Examples of a New Syncretistic Medium in Contemporary Polish Music
}

\begin{abstract}
This essay analyses and interprets the scores, recordings, and media used in Knittel and King's The Heart Piece - Double Opera (1999) and Stulgińska's Three Women for three women and ten instruments (2017), two semi-improvised Polish operas using performance art and interaction between sound, text, choreography, lighting, theatrical form and electronic medium.

In Stuglińska's modern music theatre, the listener follows different sound sources and the setting: choreography, performers' and speakers' arrangement on stage, props and lighting, whose intensity dictates the form. The Heart Piece chamber opera is a two - Polish and American - composers' take on Müller's play Herzstück, with separate movements in their native languages. Music and text create an interactive setting, and their notation and semantics make music both seen and heard.

These works use the concept of hybridization and, in Wolf's terminology, intracompositional intermediality, where different means of expression create an intermedial discourse, a complementary whole and a new syncretistic medium.
\end{abstract}

Keywords: intermediality, intertextuality, live performance, contemporary Polish music, modern musical theatre and opera.

\section{Introduction. Methodological issues}

New technologies and the development of new media provide a universal and unlimited access to multimedia content and, additionally, change the process of creating and experiencing music. As a result, compositions are written in which the very process is perceived as a basic medium of creative expression. The concept of the medium itself in the context of artistic creation, however, is elusive and requires further clarification during this presentation. 
Media changes and co-relations between media are important tendencies in the development of the arts since the beginning of the twentieth century. These are usually associated with the blurring and crossing boundaries between media; with the hybridisation of media utterances; with intertextual relationships between media; with intermedial relationships between media; and with an increasing self-reference and selfreflection of the arts as media (Kattenbelt, 2008: 21)

The compositions selected for analysis, written at the beginning of the twenty-first century, are intermedia works which, on the one hand, reveal their hybrid morphology conditioned by intentions and, on the other hand, become a new artistic phenomenon that conveys a new message and displays new quality.

In addition, a host of related terms has surfaced in the discourse about intermediality which are themselves defined and used in a variety of ways (e.g. multimediality, plurimediality, crossmediality, inframediality, mediaconvergence, media-integration, media-fusion, hybridization, and so forth). More recently, researchers have begun to formally specify their particular conception of intermediality through such epithets as transformational, discursive, synthetic, formal, transmedial, ontological, or genealogical intermediality, primary and secondary intermediality, or so-called intermedial figuration. (Rajewsky, 2005: 44)

At this point, it is necessary to define the medium of art in terms of artistic creation. The artistic milieu interprets it as a conventionally regarded, classical, manual means of artistic expression [...], moreover, it is thought that the medium of art is basically characterised by the matter in which a work, an artistic utterance, is shaped. The medium of sculpture may then be defined by brass, wood or marble, while in other art forms the medium will be oil paint, gouache, tempera, pastel or ink. We may thus say that in the traditional, institutional context of art, the concept of medium comprises the disciplines (forms) of artistic creativity and their material or, to put it another way, any structural-material indicators of art, which are manifested in their combination in the form of artefacts (Kluszczyński, 2019: 26).

„Intermediality is neither the sum of various media concessions nor the placement of particular works among the media, but the integrating of the aesthetic concepts of particular media into a new media context" (Müller, 1999: 12-21). ${ }^{1}$ As rightly observed by Irina O. Rajewsky:

While a fair amount of overlap occurs between the different disciplinary perspectives on intermedial phenomena, it is still possible to identify

1 Quoted from the Polish edition: 'Intermedialność jako prowokacja nauki o mediach', Od projektora do komputera. Współczesna niemiecka myśl filmowa. Antologia, trans., ed. Andrzej Gwóźdź (Katowice: Wydawnictwo Naukowe „Śląsk,"1999), p. 152. 
certain common tendencies: for instance, approaches coming out of literary, or so-called media-philological studies primarily emphasize the forms and functions of intermedial practices in given media products or medial constellations. (Rajewsky, 2005: 49)

„A conceptual blend of various elements results in a palimpsest score in which each of the forms reveals its characteristic features that serve the purpose of projection of vocal gestures existing in the pre-linguistic domain, and musical gestures, equivalents to the sound of contemporary music styles, which fulfil an expressive function" (Pietruszewska-Kobiela, 2012: 276-277). These processes develop the socalled intermedia strategies (Hopfinger, 2003: 72).

Two stage works by contemporary Polish composers have been selected for discussion: The Heart Piece - Double Opera (1999) by Krzysztof Knittel and John King and Three Women for three women and ten instruments (2017) by Agnieszka Stulgińska. Both create an intermedia spectacle embracing performance art according to Dick Higgins, exploring the symbolic meaning of sound production interacting with the text of the play, stage choreography, lighting and scenic design, theatrical form, digital technology (environment and programming language designed for realtime synthesis and processing of sound) as well as another electronic medium (sound design). The compositions resemble palimpsests and may be based on 'a comparison of poetics which are founded on semiological criteria characteristic of a given medium' (Regiewicz, 2014: 57-8). In this case, the medium, in a broad sense, comprises not only sound generators, i.e. a classical, electronic or digital medium, but also elements of choreography or scenery of music theatre.

The selected works represent, according to Werner Wolf's theory, overt intracompositional intermediality. Within this framework of intermediality, the interrelations between particular media (fusion, combination) may be transferred onto other media, such as music theatre, ballet, comic book, film, illustrated stories or opera (Wolf, 2002: 22, 28). The fusion of various means of expression creates an intermedia discourse, an organic whole and the final artistic result that is a new syncretistic medium.

While attempting to analyse and interpret such a complex and ambiguous work, one may refer to the concept of literary stylisation formulated by Stanisław Balbus (Balbus, 1993). Its main feature is the tension resulting from two languages and styles coexisting in one work. According to Balbus, styling, as a variant of broadly defined intertextuality, is meant to emphasise intertextual relations, i.e. intertextual and interstylistic connections (Wolf, 2002: 19). Also relevant to musical works, particularly those written at the turn of the twentieth and twenty-first centuries are, however, the intertextual strategies described by Balbus in the second part of his treatise. They include active continuation and epigonism, restitution of the form, open imitation of models, stylistic reminiscence, stylistic reminiscence versus primarily conversational 
strategies, cultural transposition of a theme, transposition of a theme versus styling, and styling as interpretation of tradition.

Mieczysław Tomaszewski, a music theoretician, musicologist and author of a holistically grounded integral interpretation of the musical work, undertook research into analogous issues in the field of music (Tomaszewski, 2000). The terms that he introduced into intertextual musical analysis include music within music, music versus music, music beyond music, music from music (Tomaszewski, 2012:23), inclusive music (Tomaszewski, 2005:2 5-6) or retroverse music (Tomaszewski, 2005: 25-6). Tomaszewski emphasises that it is not possible to fully define all of the ways in which the old coexists with the new or the intrinsic with the extrinsic. Exploring the abovementioned strategies in the analysis of the selected compositions will have helped indicate the presence of excerpts from other texts and of topoi (Hatten, 2004: 2) ${ }^{2}$ which perform important expressive and narrative functions in a given work.

In other words, such a methodological approach will have made it possible to identify and describe what, for a given work, constitutes its originality and novelty, or its differentia specifica.

\section{The Heart Piece - Double Opera. Intertextual and intermedia strategies}

The origin of the opera

The Heart Piece - Double Opera is a contemporary chamber opera about love, composed to the text of the play Herzstück by the German playwright Heiner Müller. The idea of the opera built around the dialogue between the main characters came from the New York composer John King. He invited his Polish colleague Krzysztof Knittel to collaborate on the work. Interestingly, they took turns writing the movements in their native languages. Music and text, consequently, inspired a live scenery, where, in Krzysztof Zarębski's words, 'performance art meets opera', and juxtaposition of the onstage action and the text and music offered a new area of interpretation.

The title Double Opera is not accidental. The term 'double' refers to its dichotomous building blocks: two composers, two languages (Polish and English), two different cultures, two styles, and two great singers (the Polish soprano and the American 'improvising bass/tenor'). When setting the love story of Müller's work to music, both composers accounted for the political, cultural and personal aspects of a relationship between two people present in the text of the play in any place and time, regardless of social class, nationality, race, sexual preferences or distinct identity. In this way, a duality of a 'relationship' was created, reflected in the theme of the opera of any

2 Robert Hatten defines topos as 'Topoi (topics) are fragments of music which evoke clear associations with styles, genres and expressive meanings'. See Robert S. Hatten, Interpreting Musical Gesture, Topics, and Tropes. Mozart, Beethoven, Schubert (Musical Meaning and Interpretation) (BloomingtonIndianapolis: Indiana University Press, 2004), p. 2. 
two people and their struggle for communication and understanding. This dichotomy and love seem to function as the opera's message.

The collaboration involved the composers, who also performed the work (John King - electric guitar, voice; Krzysztof Knittel - synthesiser, voice), two great soloists (Olga Pasiecznik - soprano, David Moss - percussion, voice), the Dafô String Quartet, as well as Krzysztof Zarębski (scenic design, performance art), Maciej Wojtyszko (director), Tadeusz Sudnik (sound design) and Jan Pieniążek (lighting design).

The premiere, directed by Maciej Wojtyszko, was given at Mały Teatr in Warsaw in 1999 during the $42^{\text {nd }}$ Warsaw Autumn International Festival of Contemporary Music.

The work is a musicalisation of a tragicomic love story between two characters, $\mathrm{A}$ and $\mathrm{B}$ (cf. Figure 1).

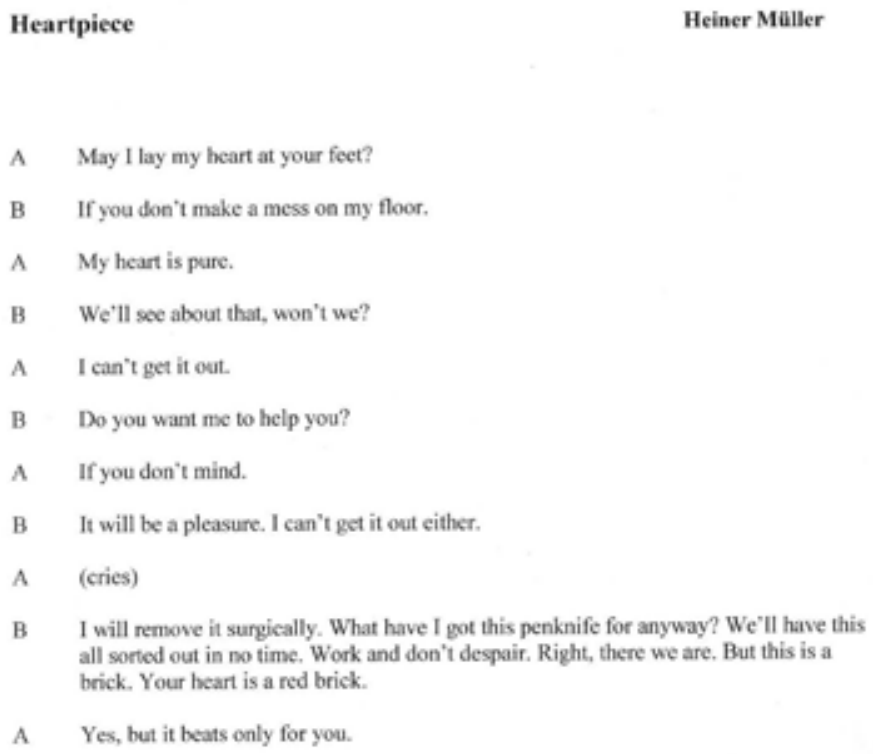

(1981)

$A$ bears $B$ to death with the brick.

(addition, July 1991)

Iranslated by John King

Figure 1. K. Knittel, J. King, The Heart Piece - Double Opera, scene 1 (text of the play), courtesy of Krzysztof Knittel. 
Sung or recited by the characters, the text combines with music in various styles (high and low culture, traditional and modern culture) in such a way as to explore a multitude of meanings. The composition is a musical interpretation of the Dadaist approach to the classical form created independently by two composers (the scenes were combined in an alternating manner). „Both in its content and in its form, the opera is surrealist and absurd, uses avant-garde musical devices, mocks tradition, breaks musical routines“ (Knittel, King, 2019).

\section{The verbal layer and the sphere of meanings}

Besides the music and the scenery, the verbal layer constitutes an equally important element of this opera, in certain movements even having a primary function (part 1 - The Heart Piece - Theme; part 4 - Hepyent Trio; part 7 - Miron's Aria; part 15 - Tutti.1; part 16 The Heart Piece - Fugue). The verbal layer of the work is based on various sources, whose stylistic and semantic features indicate the use of original texts and connections with the popular culture. Apart from the libretto based on the Müller's play, the sources include excerpts from the following works: William Shakespeare's Romeo and Juliet (translated into Polish by S. Barańczak), Robert Browning's Women and Roses, Karen Blixen's Seven Strange Stories, A. E. Housman's Fragment of an English Opera, Miron Białoszewski's Przejęcia and Hepyent, Girolamo Frescobaldi's Aria a voce sola Se l'onde, ohimè.

The fugue is a radical example of Knittel's employment of symbolic wordplay. Müller's text is used as the musical material of the fugue and is recited in three different languages by the musicians. The triple fugue in which each subject is presented in a different language (subject 1 in Polish, subject 2 in English, subject 3 in German) deviates from the Baroque model despite the use of traditional formal elements, i.e. subject, episode, free polyphonic transformation (augmentation, diminution, retrograde). Lack of definite pitches excludes the appearance of the other principles underlying the genre. What happens in this case is an interaction and fusion of different media, with emphasis on the hybrid nature of the visual score notation. In the fugue, the key importance does not lie in the semantics of the poetic text itself but on the timbral materialness of the text. This part of the opera may be compared to an intermedia optophonic poem notated as a score, in which the spatial notation translates into a simultaneity of sound that is paradigmatic for music" (Wasilewska-Chmura, 2011: 279). The fugue is, therefore, an exemplification of broadly defined intermediality, where ,within a given medium, an attempt is made to follow the aesthetic conventions and/or visual and aural characteristics of a different medium" (Balme, 2002: 204).

The score notation allows for the possibility to perform the work in two variants: first being a verbal-only version, second being a verbal version with instruments. The original notation, illustrative of the imitation of themes, is conducive to interpreting the intention of the form. Figures 2(a) and 2(b) below present the first two pages of the score. 
The scene Miron's Aria, in turn, is an example of three performers' improvised declamation of Miron Białoszewski's poem Przejęcia. The absence of a musical score produces a verbal performance art resembling wild gesticulation. Knittel noted only the poem's text, in which only selected words are uttered by all the performers, assigning symbolic meaning to the former. The title becomes a metaphor since, as a result, the scene may be labelled as an 'anti-aria'.

For scene xv, Tutti 1, John King devised a melodeclamation of specific single words - personal pronouns - whose melodic-rhythmic replicas create an asemantic discourse. This verbal material forms a cohesive continuum accompanied by Zarębski's installation.

\section{The form and active scenery}

This opera is a so-called media hybrid, i.e. an artefact which is, by nature, unclassifiable, indefinable, avant-garde par excellence and difficult to listen to, as its creative process involves mixed media (verbal text, musical text, electronic media, digital media, lights, set design, choreography) to form a cohesive whole. The unifying force behind this project is the connection between the opera and semantic poetry, whose overriding theme is love. As a result, this composition deviates from traditional opera, where music, libretto and scenic design exist independently. The musical structure of Heart Piece is not autonomous, but subordinated to the verbal layer, scene dialogue and performance, and the abandoning of the traditional practice leads to the conclusion that this work is an asemantic opera, where, apart from the music, other media are supposed to attract attention. Also unconventional is the score notation of particular scenes, and it may be analysed from the perspective of multimedia. The scenes in which wordplay has the crucial role reflect the musical technique or an element of the scenery already in their graphic notation.

Structurally, Double Opera is a theme with variations, where the theme is the text of the play presented in part one, and the movements of the opera are variations based on this content.

In this work, the composers consciously chose to use and, in a sense, restitute the emblematic form. Drawing on the traditional opera, they divided the dramaturgy into seventeen independent parts (scenes), including arias, a recitative, an arioso, a duet, trios, tuttis, a prologue (functioning as an overture) or a fugue, each given a new expressive function. In this opera, the overture is presented twice: the first time as a recitation of the text of the play in character (section 1) and the second time in the 
instrumental version featuring lights and an electronically generated track. Moreover, there are parts which embrace both avant-garde experiments with voice and bel canto, coloratura, high tessitura or parlando. The vocal expression of the soloists was combined with various experimental techniques, such as electroacoustic effects, live electronics, free improvisation, real-time computer-generated music, loud screams, text declamation, Sprechgesang, symbolic wordplay or popular music (jazz, hip-hop, rock, country, western or blues). A semantic scenery layout of the opera is presented in Table 1 below.

Table 1. Scenario of The Heart Piece - Double Opera

\begin{tabular}{|c|c|c|c|c|}
\hline Section of the opera & $\begin{array}{c}\text { Author } \\
\text { John } \\
\text { King } \\
\text { (JK)/ } \\
\text { Krzysztof } \\
\text { Knittel } \\
\text { (KK) }\end{array}$ & Text & Medium & $\begin{array}{l}\text { Type of } \\
\text { section }\end{array}$ \\
\hline $\begin{array}{c}\text { 1.The Heart Piece } \\
\text { (theme) }\end{array}$ & $\mathrm{JK}$ & $\begin{array}{l}\text { complete text } \\
\text { by H. Müller }\end{array}$ & $\begin{array}{c}\text { text recited in } \\
\text { English by JK and } \\
\text { soprano }\end{array}$ & $\begin{array}{l}\text { overture - } \\
\text { theme }\end{array}$ \\
\hline $\begin{array}{l}\text { 2. Prologue with } \\
\text { Lamp }\end{array}$ & KK & & $\begin{array}{l}\text { string quartet, } \\
\text { electric guitar, drum } \\
\text { kit and electronic } \\
\text { media, active } \\
\text { scenery }\end{array}$ & $\begin{array}{c}\text { overture } \\
\text { with scenery } \\
\text { arranged live } \\
\text { on stage }\end{array}$ \\
\hline 3. Women and Roses & KK & $\begin{array}{l}\text { poem by } \mathrm{R} . \\
\text { Browning }\end{array}$ & $\begin{array}{c}\text { soprano, } \\
\text { keyboard } \\
\text { accompaniment by } \\
\text { KK }\end{array}$ & arioso \\
\hline 4. Hepyent Trio & KK & $\begin{array}{c}\text { poem by } \\
\text { Białoszewski }\end{array}$ & $\begin{array}{l}\text { text recited by David } \\
\text { Moss (DM), sampled } \\
\text { and synthesised, } \\
\text { instrumental } \\
\text { accompaniment } \\
\text { on electric guitar, } \\
\text { keyboard, computer } \\
\text { and acoustic drum } \\
\text { kit }\end{array}$ & trio \\
\hline
\end{tabular}


STUDIJE O MUZIČKOJ UMETNOSTI/STUDIES ON MUSIC

\begin{tabular}{|c|c|c|c|c|}
\hline 5. Recitativ. 1 & $\mathrm{JK}$ & $\begin{array}{l}\text { excerpts } \\
\text { from text by } \\
\text { Müller }\end{array}$ & $\begin{array}{c}\text { soprano/baritone part } \\
\text { sung in Polish, text, } \\
\text { with electric slide } \\
\text { guitar }\end{array}$ & recitative \\
\hline 6. Aria. 1 & $\mathrm{JK}$ & $\begin{array}{l}\text { excerpts } \\
\text { from text by } \\
\text { Müller }\end{array}$ & $\begin{array}{l}\text { soprano and baritone } \\
\text { parts sung in Polish } \\
\text { and English, text, } \\
\text { full ensemble (string } \\
\text { quartet, electric } \\
\text { guitar, keyboards) }\end{array}$ & aria \\
\hline 7. Miron's Aria & KK & $\begin{array}{l}\text { poem by M. } \\
\text { Białoszewski }\end{array}$ & $\begin{array}{c}\text { text recited by DM + } \\
\mathrm{JK} \text { and } \mathrm{KK}\end{array}$ & aria \\
\hline 8. Trio. 1 & $\mathrm{JK}$ & $\begin{array}{l}\text { excerpts } \\
\text { from text by } \\
\text { Müller }\end{array}$ & $\begin{array}{l}\text { excerpts from text in } \\
\text { English, one line in } \\
\text { Polish, } \\
\text { electric guitar, } \\
\text { baritone, string } \\
\text { quartet, keyboards }\end{array}$ & trio \\
\hline 9. Juliet's Aria & KK & $\begin{array}{c}\text { text by } \\
\text { William } \\
\text { Shakespeare }\end{array}$ & $\begin{array}{l}\text { sung by soprano, } \\
\text { the ensemble } \\
\text { accompaniment }\end{array}$ & aria \\
\hline 10. Tutti.2 & $\mathrm{JK}$ & $\begin{array}{l}\text { complete text } \\
\text { by Müller }\end{array}$ & $\begin{array}{l}\text { text excerpts in } \\
\text { English, full text } \\
\text { in Polish (quickly) } \\
\text { recited by musicians, } \\
\text { country and western } \\
\text { 'song' full ensemble, } \\
\text { live electronics }\end{array}$ & tutti \\
\hline $\begin{array}{l}\text { 11. Frescobaldi - } \\
\text { Blues }\end{array}$ & KK & $\begin{array}{c}\text { lyrics by KK, } \\
\text { text by } \\
\text { Frescobaldi }\end{array}$ & $\begin{array}{l}\text { mixture of a theme } \\
\text { from Frescobaldi } \\
\text { (sung by soprano) } \\
\text { with guitar blues } \\
\text { by JK, lyrics by } \\
\text { KK, chords played } \\
\text { by string quartet, } \\
\text { hip-hop electronic } \\
\text { percussion, and free } \\
\text { improvisation on } \\
\text { percussion by DM, } \\
\text { electronic media }\end{array}$ & tutti \\
\hline
\end{tabular}


STUDIJE O MUZIČKOJ UMETNOSTI/STUDIES ON MUSIC

\begin{tabular}{|c|c|c|c|c|}
\hline 12. Tutti.3 & JK & $\begin{array}{l}\text { Excerpts } \\
\text { from text by } \\
\text { Müller }\end{array}$ & $\begin{array}{l}\text { text excerpts in } \\
\text { English, string } \\
\text { quartet, electric } \\
\text { guitar, drum kit, } \\
\text { keyboard }\end{array}$ & tutti \\
\hline 13. Family Duo & KK & $\begin{array}{l}\text { A. E. } \\
\text { Housman's } \\
\text { Fragment of } \\
\text { an English } \\
\text { Opera }\end{array}$ & $\begin{array}{l}\text { vocal duet of Olga } \\
\text { Pasiecznik (as } \\
\text { Daughter) and } \\
\text { DM (as Father and } \\
\text { Mother) }\end{array}$ & duet \\
\hline 14. KZ-action & $\mathrm{KZ}$ & $\begin{array}{c}\text { A.E. } \\
\text { Housman's } \\
\text { Fragment of } \\
\text { an English } \\
\text { Opera }\end{array}$ & $\begin{array}{l}\text { installation by KZ, } \\
\text { electronic media, } \\
\text { soft recording (voice } \\
\text { accompanied by the } \\
\text { string quartet), } \\
\text { visual action on } \\
\text { stage }\end{array}$ & $\begin{array}{c}\text { visual action } \\
\text { on stage }\end{array}$ \\
\hline 15. Tutti.1 & JK & single words & $\begin{array}{c}\text { keyboards, electric } \\
\text { guitar, soprano/ } \\
\text { baritone, } \\
\text { wordplay }\end{array}$ & tutti \\
\hline $\begin{array}{l}\text { 16. Heart Piece } \\
\text { Fugue }\end{array}$ & KK & $\begin{array}{l}\text { complete text } \\
\text { by Müller }\end{array}$ & $\begin{array}{c}\text { text recited by } \\
\text { musicians in English, } \\
\text { German and Polish } \\
\text { or } \\
\text { text with the string } \\
\text { quartet }\end{array}$ & fugue \\
\hline 17. Prefinale-Finale & JK & $\begin{array}{l}\text { the word } \\
\text { 'yes' and } \\
\text { excerpts } \\
\text { from text by } \\
\text { Müller }\end{array}$ & $\begin{array}{c}\text { Text in English } \\
\text { and Polish, full } \\
\text { ensemble, electric } \\
\text { guitar, keyboards, } \\
\text { drum kit, string } \\
\text { quartet, soprano, } \\
\text { baritone }\end{array}$ & finale, tutti \\
\hline
\end{tabular}

It is also possible to identify in the opera a strategy based on stylisation and overt references to patterns (e.g. scene ix, Juliet's Aria; scene x, Tutti.2; scene xi, Frescobaldi - Blues). The pattern, already revealed in the title of the movement, is Frescobaldi's music style. Knittel quotes passages from the cantilena aria a voce sola $\mathrm{Se}$ l'onde, ohimè, which the soprano sings to the blues-style accompaniment of the string quartet, percussion and live electronics. 
Scene $\mathrm{x}$, in turn, is an example of employing a completely recognisable stylisation of country and western music (rhythmic motifs, instrumentation, singing style), which John King combined with text declamation and the effect of the performers' screams.

These timbral-stylistic representations acquire, in the aforementioned parts, the meaning of intertextually overt structures; of the musical topoi of both popular and art music styles (early and modern).

The music and text of this work formed the basis for an active scenery being set up live during the performance. It is worth noting that the main element of the stage set is an enormous paper 'lamp' or, more precisely, a lampshade inside which the women string quartet is seated. In scene ii (Prologue with Lamp), the director destroys the lamp in which the performers are playing.

Additionally, in scene xiii, Family Duo, Zarębski's installation is presented (dummies placed on the music stand, the lighting and the blowing out of a candle), accompanying the performers' stage action. The display features a photocell that reacts to body movement, triggering a recording played from the sampler (voice accompanied by the string quartet). The title duo is performed by two soloists using the Sprechgesang technique, where the soprano performs the part of the Daughter, while David Moss performs the parts of the Father and the Mother alternately (Cf. Example 1).

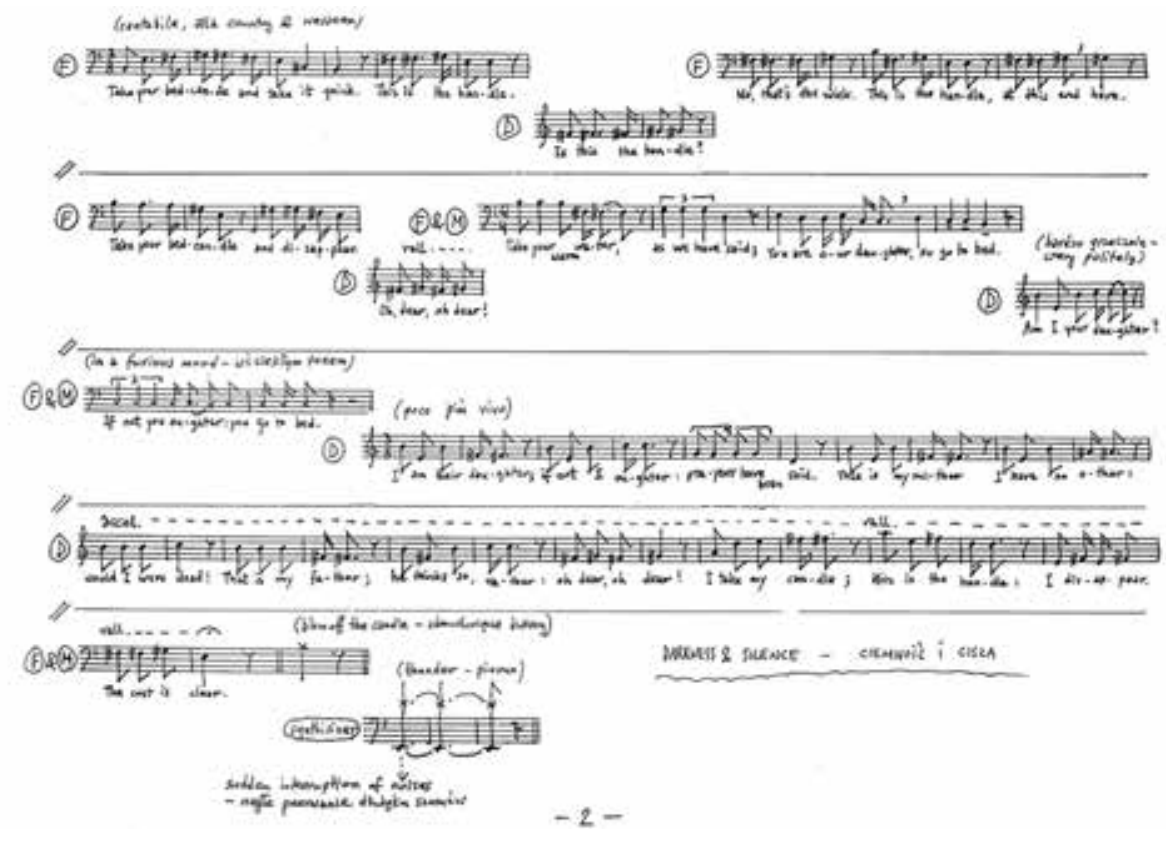

Example 1. Knittel and King, The Heart Piece - Double Opera, scene xiii (the second page of the score), by kind permission of Krzysztof Knittel. 
A commentary is also needed on the last movement of the opera, scene xvii Prefinale-Finale. The music is performed by all the artists with all the media (electronic, digital, traditional, literary text, scenery). The string quartet and the soprano play and sing their parts from a traditionally notated score, first in a 6/8 metre (Prefinale), then in 4/4 (Finale), while the remaining performers accompany them, improvising music in a variety of styles. Example 2 shows the music accompanied by the word yes recited repeatedly by the whole ensemble, to the rhythm of musical narration.

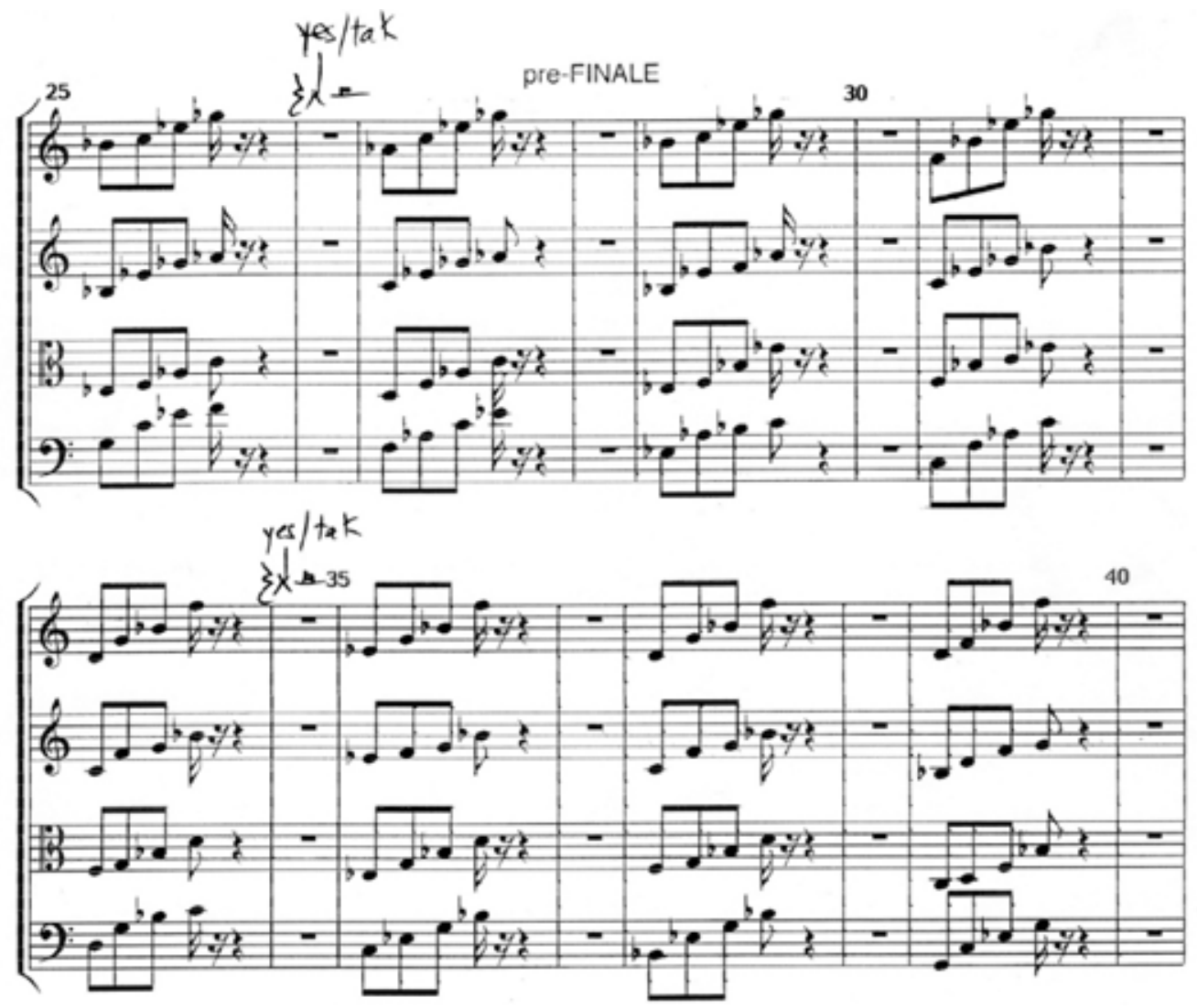

Example 2. Knittel and King, The Heart Piece - Double Opera, scene xvii (Prefinale), mm. 25-40, courtesy of Krzysztof Knittel. 


\section{'Three Women'for three women and ten instruments: a live intermedia opera}

Agnieszka Stuglińska's $\mathrm{s}^{3}$ composition is an example of intermedia music theatre, whose content relates to women in difficult predicaments. The work's dramaturgy comprises four scenes that illustrate different situations in which the women mentioned in the title (the conductor, the vocalist and the flutist) find themselves. The composer assigned each woman a different role to play in this music theatre, such as sitting, singing, conducting, pouring grain, pouring water or stirring pots in pretend cooking. These activities refer to the message carried by a given folk song. Stulgińska made use of original ritual chants from the Ukrainian part of the Polesia region, which function in her work as stylisation. In scene i the composer introduced the song Oj $u$ w sadusadu, which was the inspiration behind the whole work, sung by two, young and old, women folk singers in the so-called white voice singing technique, and in scene iii she included a song about a widow Oj szczo eto za werba. In scene iv, we hear vocal improvisations on the vowels $/ \mathrm{a} /, / \mathrm{J} /, \mathrm{u} /$ and $/ \varepsilon /$ performed to the pulsating bass accompanied by white voice.

Listing the particular media in the work is only possible when following the live spectacle or its video recording, the reason being that the soundtrack itself does not convey precisely the message which the composer wrote in the score. The following media were used in order to create this intermedia work:

- classical medium: traditional instruments (string quintet, wooden and metal simantra, baritone saxophone, flute, white voice singing (folk singer Maniucha Bikont), and objects which produce percussive sounds: grain, bowls, dry leaves, twigs, cones and nutshells, water);

- electronic medium: tape of white voice singing by Dominika Czekun, the older woman who sings a folk song from the Stari Koni village in Rivne Polesia (emitted from a small speaker);

- digital medium: a computer with Ableton Live software for processing voice and instrumental sound;

- theatrical medium: division into scenes, acting, scenery with props;

- light medium: the lighting of the stage set.

The listener follows both the sounds produced by various sources and the elements of the performance art (the performers' body movements, the speakers' and their placement on stage, props and lighting).

\footnotetext{
3 For more information, see Monika Karwaszewska, Anna Galikowska-Gajewska, 'Sounds and Computer - Artistic Message', XXI Generative Art 2018, ed. Celestino Soddu and Enrica Colabella (Milan: Domus Argenia Publisher, 2018), pp. 264-277.
} 
Light emerges as the main factor behind the form and symbolism of the work. The varying intensity of stage set lighting divides the work into particular movements: scene i - no light; scene ii - dim light illuminating first the conductor, then the woman sitting on the floor, occupied with breaking twigs, leaves and nutshells, throwing them into a bowl and stirring; scene iii - no light, as in scene i; scene iv - full illumination of the three women: the conductor and two women stirring peas, rice and wooden pellet cat litter in aluminium pots, following a rhythmic pattern, as seen in Figure 3. Lack of light ,is, in turn, a psychoacoustic element - it prompts listening to a voice from behind a wall and the one coming from a small speaker. ${ }^{64}$ What also changes in particular scenes is the music material, folk melody and the performing cast.

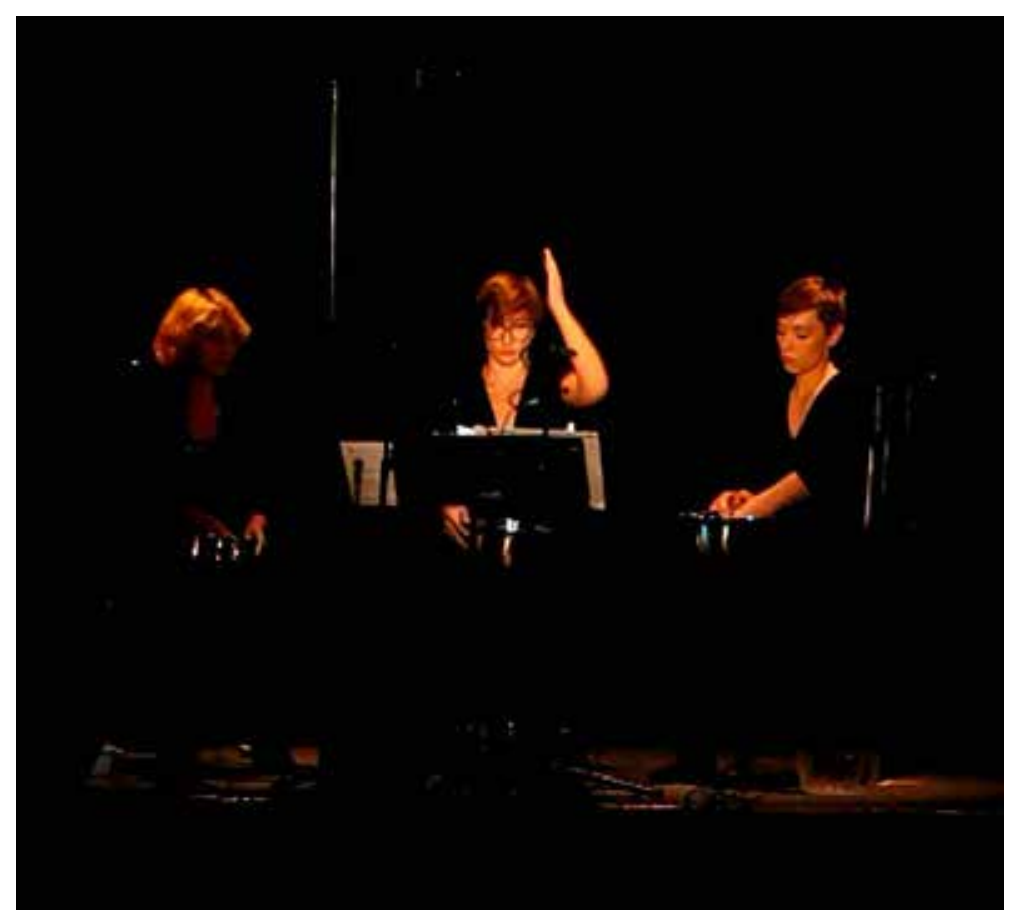

Figure 3. Stulgińska, Three Women for three women and ten instruments, scene iv. Concert 27. Composers' portraits, 2017. Anna Karpowicz, Lilianna Krych, Marta Bogusławska-Grzywacz (Photo by Agnieszka Stulgińska).

Other aspects that draw the audience's attention are the performers' body movements and symbolic gestures, which become not only a new medium but also generators of musical expression and, by the same token, a distinctive building block of the opera's theatricality.

4 Information obtained from Agnieszka Stulgińska. 
The conductor's unconventional method of conducting represents a quintessential example. Stulgińska, apart from the traditional coordination of the performers' play, entrusts her with improvising the gestures which accompany the woman's and the musicians' voices (circular, upward-downward, side-to-side and jerky motions) as well as with active participation in the performance.

In scene ii, the conductor's gestures (Woman 2) are replicated by one woman sitting on the floor (Woman 1) and stirring the contents of a bowl with her left hand, while showing the conductor's gestures with her right hand. As illustrated by Example 3, the women's hand movements form an additional element of choreography. The visual dimension of the music notation employed by Stulgińska is highlighted by its graphic character, with pictograms being a direct representation of the course of musical events.

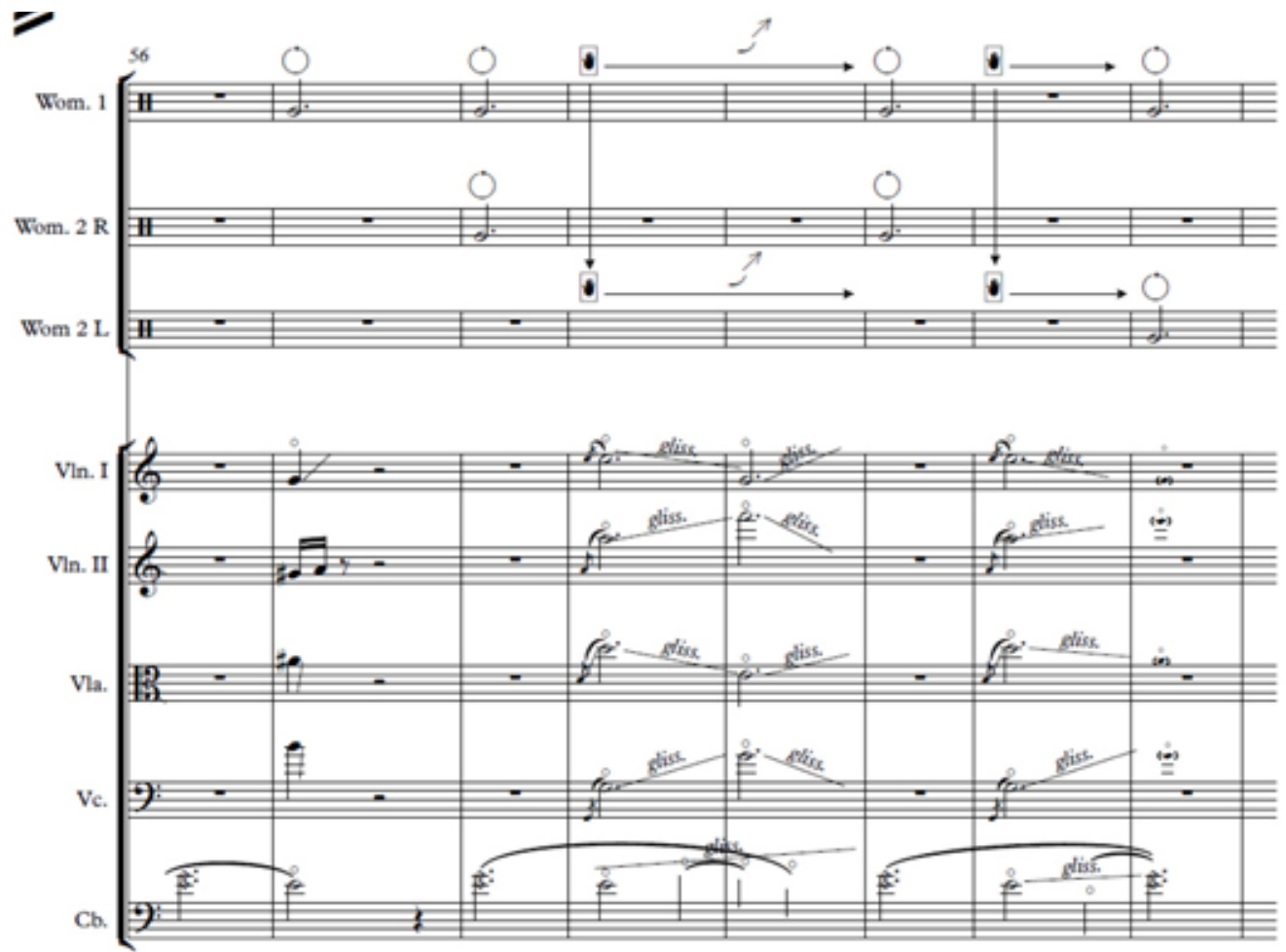

Example 3. Stulgińska, Three Women for three women and ten instruments, scene ii, mm. 56-63, courtesy of Agnieszka Stulgińska.

In scene ii, the composer introduced improvised singing. One of the women interprets a song from Polesia by improvising a tune on the sounds she hears while simultaneously drawing in the air the shapes of an orchard, flowers, garden and forest 
using her hands. This may be categorised as gestural performance art in which one may experience a phenomenon described by Paul Théberge, i.e. „a physical - structural match between a gesture and the sound that arises from it" (Théberge, 1997: 199). The audience has the opportunity to analyse in real time the synergy of performing and assigning meanings to gestures.

\section{Conclusion}

This article presented an analysis of a new type of stage form - an intermedia spectacle - a performance with original content and form of message, reveals the symbolic meaning of sound emission interacting with choreography, light, theatrical form and another electronic medium. The time of creation and the technologies used in the process exclude the possibility to analyse the two works within the framework of traditional stage forms. They are works in which autonomy is transferred from the formal level to the material level generated by various media, resulting in one, 'polymedia' whole. The dimension of the musical gestures and symbols used in the two compositions determines their aesthetic meaning. For research on the changes in, and the interrelations among, the media, interdisciplinary arts practice is the main point of reference. The adopted methods relying on intertextual and intermedia strategies, made it possible to evaluate the original 'created text' (or, a new intermedia work created with new media; an intermedia, visual spectacle) based on the performative aspect. There is no doubt that the compositions are examples of works in which the interference between ars and techne determines their aesthetic value. In both compositions, the medium of light provides an excellent example of the raw material for artistic artefacts based on projection or emission.

\section{REFERENCES:}

1. Balbus, S. 1993. Międzystylami. Kraków: Universitas.

2. Balme, Christopher. 2002. Einführung in die Theaterwissenschaft. Quoted from the Polish edition: Wprowadzenie do nauki o teatrze. trans. Wojciech Dudzik and Małgorzata Leyko. Warszawa: Wydawnictwo Naukowe PWN.

3. Hatten, Robert S. 2004. Interpreting Musical Gesture, Topics, and Tropes. Mozart, Beethoven, Schubert (Musical Meaning and Interpretation). Bloomington-Indianapolis: Indiana University Press.

4. Hopfinger, Maryla. 2003. Doświadczenia audiowizualne. O mediach w kulturzewspótczesnej. Warszawa: Wydawnictwo "Sic!".

5. Karwaszewska, Monika, Galikowska-Gajewska, Anna. 2018. „Sounds and ComputerArtistic Message.“ XXI Generative Art 2018, edited by C. Soddu and E. Colabella, 264-277. Milan: Domus Argenia Publisher. 
6. Kattenbelt, Chiel. 2008. „Intermediality in Theatre and Performance: Definitions, Perceptions and Medial Relationships.“ Cultura, lenguaje y representación: revista de estudiosculturales de la UniversitatJaume I, [en línea], Vol. 6; 19-29. https:/www.raco.cat/index.php/CLR/ article/view/226334 [Consulta: 29-04-2021].

7. Kluszczyński, Ryszard W. 2019. „Estetyka sztuki nowych mediów,“ Międzyuczelniana specjalność multimedialna, UMFC, Warszawa, Retrieved on $8^{\text {th }}$ August 2019 from the World Wide Web<https://docplayer.pl/6755862-Ryszard-w-kluszczynski-estetyka-sztuki-nowych$\underline{\text { mediow.html }>}$

8. "Krzysztof Knittel, John King. Heart Piece - Double Opera." 2019. Culture.pl, Retrieved on $4^{\text {th }}$ August 2019 from the World Wide Web $<$ https://culture.pl/pl/dzielo/krzysztof-knittel-johnking-heart-piece-double-opera $>$

9. Müller, Jürgen E. 1992. „Intermedialität als Provokation der Medienwissenschaft.“ Eikon. Internationale Zeitschrift für Photographie \& Medienkunst, 4, 12-21; trans. Andrzej, Gwóźdź. 1999. „Intermedialność jako prowokacja nauki o mediach.“ Od projektora do komputera. Wspótczesna niemiecka myśl filmowa. Antologia, edited by Andrzej Gwóźdź, 129-156. Katowice: Wydawnictwo Naukowe "Śląsk".

10. Pietruszewska-Kobiela, Grażyna. 2012. „Poezja konkretna i muzyka.“Folia Litteraria Polonica, 1:15, 267-282.

11. Rajewsky, Irina O. 2005. „Intermediality, Intertextuality, and Remediation: A Literary Perspective on Intermediality." Intermédialités / Intermediality, 6, 43-64.

12. Regiewicz, Andrzej. 2014. „Komparatystyka jako sposób badania nowych mediów.“ Teksty Drugie, 2, 49-70.

13. Tajber, Artur. 2019. „Wydział Intermedialny. IntermediaWKrakowie,“ Retrieved on $1^{\text {st }}$ August 2019 from the World Wide Web<http://wiki.intermedia.asp.krakow.pl/wiki/ IntermediaWKrakowie>

14. Théberge, Paul. 1997. Any Sound You Can Imagine: Making Music / Consuming Technology. Hanover, NH: University Press of New England.

15. Tomaszewski, Mieczysław. 2000. Interpretacja dzieła muzycznego. Rekonesans. Kraków: Akademia Muzyczna w Krakowie.

16. Tomaszewski, Mieczysław. 2012. „Odczytywanie dzieła muzycznego. Od kategorii elementarnych do fundamentalnych i transcendentnych.“ Teoria Muzyki. Studia, Interpretacje, Dokumentacje, 1, 7-50.

17. Tomaszewski, Mieczysław. 2005. „Utwór muzyczny w kontekście czasu i miejsca.“ Dzietomuzyczne. Estetyka, struktura, recepcja, 11-36. Bydgoszcz: Akademia Muzyczna im. FeliksaNowowiejskiego w Bydgoszczy.

18. Wasilewska-Chmura, Magdalena. 2011. Przestrzeń intermedialna literatury I muzyki. Muzyka jako model I tworzywo w szwedzkiej poezji późnegomodernizmu I neoawangardy. Kraków: Wydawnictwo Uniwersytetu Jagiellońskiego. 
19. Wolf, Werner. 2002. „Intermediality Revisited Reflections on Word and Music Relations in the Context of a General Typology of Intermediality. “ Essays in Honour of Steven Paul Scher and on Cultural Identity and the Musical Stage, edited by S.M. Lodato, S. Aspden and W. Bernhart, Word and Music Studies 4, 13-34. Amsterdam/New York, NY: Rodopi.

\section{Kamerna opera Kšištofa Nitela i muzičko pozorište Agnješke Stulginske: primeri novog sinkretističkog medija u savremenoj poljskoj muzici}

Apstrakt: Ovaj esej analizira i interpretira partiture, snimke i medije korišćene u Nitelovom i Kingovom delu „The Heart Piece - Double Opera“ [Komad srca - dupla opera] (1999.) i Stulginskinom delu „Three Women“ [Tri žene] za tri žene i deset instrumenata (2017.), dve poluimprovizovane poljske opere koje koriste performans i interakciju između zvuka, teksta, koreografije, rasvete, pozorišne forme i elektronskog medija.

U Stulginskinom modernom muzičkom pozorištu, slušalac prati različite izvore zvuka i mizanscen: koreografiju, raspored izvođača i zvučnika na pozornici, rekvizite i rasvetu, čiji intenzitet diktira formu.

Kamerna opera „The Heart Piece,“ delo dvojice kompozitora - poljskog i američkog, zasniva se na Milerovoj drami „Herzstück“ [Komad srca] i sadrži odvojene stavove na njihovim materinjim jezicima. Muzika i tekst stvaraju interaktivni mizanscen, a njihov zapis i semantika omogućavaju muzici da se i vidi i čuje.

Ovadelakoriste koncepthibridizacije i, prema Volfovoj terminologiji, interkompozicionu intermedijalnost, gde različita izražajna sredstva stvaraju intermedijalni diskurs, komplementarnu celinu i novi sinkretistički medij.

Ključne reči: intermedijalnost, intertekstualnost, izvođenje uživo, savremena poljska muzika, moderno muzičko pozorište i opera. 